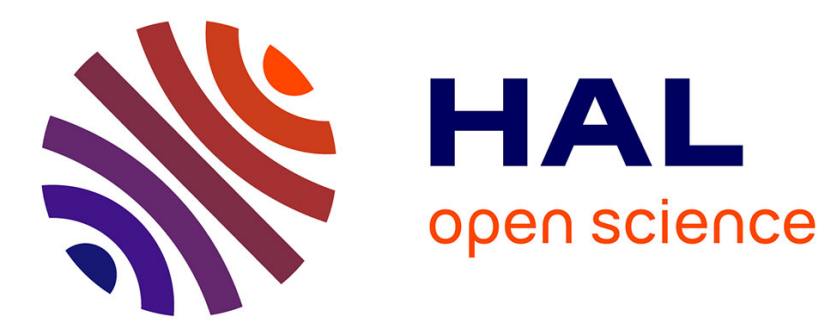

\title{
Nutritional value of tomatoes ([i] Solanum lycopersicum[/i] L.) grown in greenhouse by different agronomic techniques
}

Daniela Erba, M. Cristina Casiraghi, Albert Ribas, Rafaela Cáceres, Oriol Marfà, Massimo Castellari

\section{To cite this version:}

Daniela Erba, M. Cristina Casiraghi, Albert Ribas, Rafaela Cáceres, Oriol Marfà, et al.. Nutritional value of tomatoes ([i]Solanum lycopersicum[/i] L.) grown in greenhouse by different agronomic techniques. Journal of Food Composition and Analysis, 2013, 31 (2), pp.245-251. 10.1016/j.jfca.2013.05.014 . hal-01292344

\section{HAL Id: hal-01292344 \\ https://hal.science/hal-01292344}

Submitted on 22 Mar 2016

HAL is a multi-disciplinary open access archive for the deposit and dissemination of scientific research documents, whether they are published or not. The documents may come from teaching and research institutions in France or abroad, or from public or private research centers.
L'archive ouverte pluridisciplinaire HAL, est destinée au dépôt et à la diffusion de documents scientifiques de niveau recherche, publiés ou non, émanant des établissements d'enseignement et de recherche français ou étrangers, des laboratoires publics ou privés. 


\title{
Nutritional value of tomatoes (Solanum lycopersicum L.) grown in greenhouse by different agronomic techniques
}

\author{
Daniela Erba $^{\mathrm{a}, *}$, M. Cristina Casiraghi ${ }^{\mathrm{a}}$, Albert Ribas-Agustí ${ }^{\mathrm{b}}$, Rafaela Cáceres ${ }^{\mathrm{c}}$, \\ Oriol Marfà $^{\mathrm{c}}$, Massimo Castellari ${ }^{\mathrm{b}}$ \\ a Department of Food, Environmental and Nutritional Sciences (DeFENS), University of Milan, Via Celoria, 2, Milano 20133, Italy \\ ${ }^{\mathrm{b}}$ Institute for Food and Agricultural Research and Technology (IRTA), Granja Camps i Armet, Monells 17121, Girona, Spain \\ ${ }^{c}$ Biosystems Engineering and Agronomy (IRTA), Ctra. De Cabrils s/n, Cabrils 08348, Barcelona, Spain
}

Keywords:

Tomato

Carotenoids

Phenolic compounds

Minerals

Trace elements

Ascorbic acid

Food composition

Food analysis

Horticulture and nutritional content

\begin{abstract}
A B S T R A C T
The relevance of agronomic practices on the nutritional quality greenhouse-grown tomatoes has been recognized. We investigated the influence of (1) cultivar: two local (Pera-Girona and Montserrat) and one commercial (Caramba) varieties; (2) nitrogen dose in nutrient solution (low vs. standard N dose); (3) treatment for plant disease control (sulfur vs. Milsana ${ }^{\circledR}$ ) and (4) ripeness (orange vs. full-red color) on levels of carotenoids, phenolic compounds, ascorbic acid and minerals of fruits. Carotenoids and ascorbate were mainly influenced by variety and ripening stage, while $\mathrm{N}$ dose slightly affected minerals in fruits; treatments against plant diseases exerted only negligible effects on measured compounds. Local tomato varieties appear more promising as food source of carotenoids, mainly lycopene, and of hydroxycinnamates, such as 5-caffeoylquinic acid and caffeoylquinic derivatives, than commercial variety (total carotenoids: $67.43 \mathrm{mg} \mathrm{kg}^{-1} \mathrm{fw}$ vs. $56.34 \mathrm{mg} \mathrm{kg}^{-1} \mathrm{fw}$ of Pera-Girona vs. Caramba and total hydroxycinnamates: $90.87 \mathrm{mg} \mathrm{kg}^{-1} \mathrm{fw}$ vs. $37.90 \mathrm{mg} \mathrm{kg}^{-1} \mathrm{fw}$ of Montserrat vs. Caramba, at full-red color). Tomato variety and harvest maturity of fruit were the main factors affecting nutritional value of tomatoes, while Milsana ${ }^{\circledR}$ treatment did not result in evident nutritional benefits. However, the use of this elicitor might be appropriate considering the increasing environmentally friendly attitudes of consumers.
\end{abstract}

\section{Introduction}

Tomato is one of the major food crops worldwide, representing the second highest produced and consumed vegetable in western countries (Willcox et al., 2003). Together with its derived products, tomatoes are one of the major food sources of carotenoids, providing an estimated $80 \%$ of daily intake of lycopene, and of folate, ascorbic acid, flavonoids, $\alpha$-tocopherol and potassium in the western diet (Bramley, 2000; Willcox et al., 2003). Several epidemiological studies have underlined the beneficial effect of tomato consumption in the prevention of chronic diseases such as cancer and cardiovascular disease (Klipstein-Grobush et al., 2000; Giovannucci et al., 2002). This effect has been attributed mainly to the antioxidant activity of tomato phytochemicals, in particular lycopene, a very efficient radical quencher capable to fight reactive oxygen species and thus avoid cell injury (Riso et al., 2004);

\footnotetext{
* Corresponding author. Tel.: +3902 50316644; fax: +390250316631. E-mail addresses: daniela.erba@unimi.it (D. Erba), maria.casiraghi@unimi.it (M.C. Casiraghi), rafaela.caceres@irta.cat (R. Cáceres), oriol.marfa@irta.cat (O. Marfà), massimo.castellari@irta.cat (M. Castellari).
}

however, several other mechanisms of the healthy action of carotenoids have been suggested (Krinsky and Johnson, 2005). In addition, tomatoes contain many other compounds, such as vitamin $C$ and phenolics, whose synergistic effects on human disease prevention should be considered (Willcox et al., 2003).

Agronomic practices have been recognized as a critical factor in determining the nutritional quality of crops (Barrett et al., 2007). Levels of bioactive food compounds in fresh tomatoes can be affected by many pre- and postharvest factors such as cultivar, ripening stage at harvest and agricultural techniques (Dumas et al., 2003). For instance, tomato cultivars significantly influence carotenoid expression and phenolic compound levels, and partially affect ascorbic acid content (Abushita et al., 2000; Slimestad and Verheul, 2009); ripening stage at harvest exerts a relevant positive effect on carotenoid levels, and specifically affects the phenolic compounds content (Gautier et al., 2008), while concentrations of vitamin $\mathrm{C}$ and some phenolic compounds tend to be positively affected by low $\mathrm{N}$ fertilization (Simonne et al., 2007; Benard et al., 2009).

Most commercial tomatoes, especially in northern European countries, are produced in greenhouses that allow better control of agronomic and environmental factors. Notwithstanding, green- 
house-grown crops are often affected by powdery mildew whose infection may result in considerable economical damage and low fruit quality, and require the use of fungicides (KonstantinidouDoltsinis et al., 2006). The growing attention of consumers toward environmentally friendly primary production has led to a search for alternative methods to control plant disease. Among these, Milsana ${ }^{\circledR}$ - the commercial name given to the extract from leaves of giant knotweed (Reynoutria sachalinensis (F: Schmidt) Nakai) has been reported to have a good protective effect against powdery mildew on cucumber as an inducer of plant defense systems (Daayf et al., 2000; Fofana et al., 2002) and on tomato (KonstantinidouDoltsinis et al., 2006), but the effect of Milsana ${ }^{\circledR}$ treatment on nutritional value has scarcely been investigated (Daayf et al., 2000).

The objectives of this study were to investigate the influence of four agronomic variables such as (1) tomato varieties (one commercial and two local), (2) level of nitrogen in nutrient solution (low vs. standard), (3) treatment against plant diseases (sulfur vs. Milsana ${ }^{\circledR}$ ) and (4) ripeness at harvest (green-orange vs. red fruits), and their reciprocal interactions, on nutritional quality of tomatoes evaluated as contents of carotenoids, ascorbic acid, phenolic compounds and minerals of fruit.

\section{Materials and methods}

\subsection{Tomato samples}

The experiment was performed in a $140 \mathrm{~m}^{2}$ multi-span greenhouse covered with plastic film. The greenhouse was located at IRTA Centre of Cabrils (Cabrils, Barcelona, Spain, $41^{\circ} 25^{\prime} \mathrm{N}, 2^{\circ} 23^{\prime}$ E, altitude $85 \mathrm{~m})$.

Tomato (Solanum lycopersicum L.) seedlings obtained from a commercial nursery were cultivated in 60 -L perlite bags. The particle size of perlite was between 0.1 and $5 \mathrm{~mm}$. Each bag contained three plants. The experiment lasted for five months (from March to July 2008). Plants were fertilized by fertigation and the nutrient solution was applied with a drip irrigation system. Pollinating wasps (Bombus terrestris L.) were introduced at 50\% opened flowers of the first truss.

A full factorial design was performed and three agronomic treatments were carried out, including: three tomato varieties were cultivated: Pera Girona and Montserrat (both locals) and Caramba (commercial variety); two nitrogen $(\mathrm{N})$ dose in nutrient solution: standard (9.50 meq $\left.\mathrm{NO}_{3}{ }^{-} \mathrm{L}^{-1}\right)$ and low (5.31 meq $\mathrm{NO}_{3}{ }^{-} \mathrm{L}^{-1}$ ). The reduced $\mathrm{N}$ dose was considered because of environmental concerns on nitrate leaching and the associated pollution (Thompson et al., 2013). Two foliar fungicide/elicitor treatments against fungi-related tomato diseases: sulfur, as a traditional approach, and an innovative approach using the elicitor Milsana $^{\mathbb{R}}$ (Biofa, Germany). The elicitor was applied at a dose of $3 \mathrm{~mL} \mathrm{~L}^{-1}$ and wettable sulfur (80\%) was applied at a dose of $2.5 \mathrm{~g} \mathrm{~L}^{-1}$. The first treatment applications were carried out on the 9th May 2008 and further foliar treatments were performed every week. Pollinators were removed from the greenhouse before treatment application and returned two days after spraying.

The sampling of the tomato fruits for nutritional analysis started on 9 June 2008 and was finished on 8 July 2008. Fruits sampled for analysis were harvested from 2 nd, 3rd or 4 th truss. Tomatoes of each plant in the experiment were collected at two ripening stages: stage 5 (green-orange) and stage 10 (red) according to the French Colour Code Guide (CTIFL, France). These ripeness stages were chosen to represent tomatoes for fresh consumption (stage 5) and for processing (stage 10). Therefore, the ripeness degree of the tomato was including as a source of variation, thus resulting in 192 tomato samples to be analyzed ( 3 varieties $\times 2 \mathrm{~N}$ dose $\times 2$ plant disease treatments $\times 2$ ripeness stages $\times 8$ replicates). After harvesting, fruits were washed with tap and de-ionized water, refrigerated at $4{ }^{\circ} \mathrm{C}$ for $2 \mathrm{~h}$, vacuum packed $(0.0115 \mathrm{MPa})$ in side-sealed aluminum bags, stored at $-80{ }^{\circ} \mathrm{C}$ and sent to laboratories for analysis. Results are expressed as $\mathrm{mg} \mathrm{kg}^{-1}$ fresh weight.

\subsection{Analysis of carotenoids}

Carotenoid contents were assessed in accordance to the method of Khachik et al. (1992) with slight modification, as previously reported (Ribas-Agustí et al., 2013). Briefly, after an exhaustive extraction with tetrahydrofuran of mixed samples (about $12 \mathrm{~g}$ or $6 \mathrm{~g}$ for stages 5 and 10, respectively), carotenoids residue was dissolved and injected in HPLC system equipped with a C18 reverse phase column (Vydac 201 TP 54, $25172 \mathrm{~cm}, 5 \mu \mathrm{m}$, Grace, SintNiklaas, Belgium) at $22^{\circ} \mathrm{C}$, and Photodiode Array Detector (Waters model 2996, Milford, MA, USA). Identification of the peaks was carried out by comparison of UV-vis spectra and retention times of eluted compounds with pure standards (lycopene purity $\geq 90 \%, \beta$ carotene $\geq 95 \%$, lutein $\geq 70 \%$ from Sigma-Aldrich, Munich, Germany; phytoene $\geq 98 \%$ and phytofluene $\geq 95 \%$ from Carote Nature, Lupsingen, Switzerland). The percentage recovery of carotenoids was determined by adding a known amount of internal standard ( $\beta$-apo- $8^{\prime}$-carotenal, Sigma-Aldrich, Munich, Germany) to each sample before extraction; recovery of this internal standard was greater than $90 \%$ for all extractions.

\subsection{Analysis of minerals and trace elements}

Approximately $100 \mathrm{~g}$ of homogenized tomato sample was lyophilized in a freeze-drier laboratory equipment (Edwards Freeze Drier Pirani 1001, IVT, Milano, Italy). Then, about $0.2 \mathrm{~g}$ of freeze-dried sample was acid digested in microwave oven (Ethos TC, Milestone, Italy) and clear solution brought to the final volume with bi-distilled water. These solutions were analyzed in an air/acetylene flame spectrometry (Perkin-Elmer Analyst 800, Waltham, MA, USA), following the instrumental condition recommended for each mineral (Ca $422.7 \mathrm{~nm}, \mathrm{Mg} 285.2 \mathrm{~nm}$, $\mathrm{Cu} 324.8 \mathrm{~nm}$, Zn $213.9 \mathrm{~nm}, \mathrm{~K} 766.5 \mathrm{~nm}$, Na $589.0 \mathrm{~nm}$, Fe $248.3 \mathrm{~nm}$ ). Phosphorus was measured by a colorimetric method by using of vanadate-molybdate reagent (Fiske and Subbarow, 1925).

\subsection{Analysis of total ascorbic acid}

The analysis of total ascorbic acid was based on the method of Lopez et al. (2005) with minor adaptations: $1 \mathrm{~g}$ of ground tomato was blended in $9 \mathrm{~g}$ of $750 \mathrm{mM} \mathrm{HPO}_{3}-1.0 \mathrm{mM}$ EDTA (SigmaAldrich, Madrid, Spain). After gentle stirring for $5 \mathrm{~min}$ at $4{ }^{\circ} \mathrm{C}$ samples were centrifuged at $10,000 \times g$ for $10 \mathrm{~min}$ at $4{ }^{\circ} \mathrm{C}$ (Beckman Coulter, Brea, CA, USA) and an aliquot of the supernatant $(500 \mu \mathrm{L})$ was mixed with $300 \mu \mathrm{L} 13.0 \mathrm{mM}$ DTT-200 mM Na${ }_{3} \mathrm{PO}_{4}$ $\mathrm{pH} 7$ buffer (Sigma-Aldrich, Madrid, Spain) and $150 \mu \mathrm{L}$ $2.5 \mathrm{mM} \mathrm{K}_{2} \mathrm{HPO}_{4}$ (Sigma-Aldrich, Madrid, Spain). Reaction was kept in the darkness at room temperature for $10 \mathrm{~min}$ and then stopped by addition of $300 \mu \mathrm{L} 2.0 \mathrm{M} \mathrm{H}_{3} \mathrm{PO}_{4}$. Samples were diluted $1: 10(v / v)$ in mobile phase $\left(0.01 \mathrm{mM} \mathrm{H}_{3} \mathrm{PO}_{4}\right)$ and filtered through $0.2 \mu \mathrm{m}$ nylon membrane.

The samples $(5 \mu \mathrm{L})$ were injected into a HPLC Agilent 1100 system equipped with a quaternary pump, ASL, and DAD detector (Agilent Technologies, Palo Alto, CA, USA). Separation was performed in a $3.0 \mathrm{~mm}$ id $\times 150 \mathrm{~mm}$ Zorbax SBAq (Agilent Technologies, Palo Alto, CA, USA) at a flow rate of $0.45 \mathrm{ml} \mathrm{min}{ }^{-1}$ and the quantification was done at $244 \mathrm{~nm}$ according to a standard curve of ascorbic acid (0-340 $\mu \mathrm{M}$ ascorbic acid, purity $\geq 98 \%$, Sigma-Aldrich, Madrid, Spain). 


\subsection{Analysis of phenolic compounds}

Phenolic acids and flavonoids were analyzed according to the method described by Ribas-Agustí et al. (2012). Briefly, $20.0 \mathrm{~g}$ of cold methanol were added to $5.0 \mathrm{~g}$ of frozen minced tomato and the mixture was sonicated ( $42 \mathrm{kHz}$ ) for $15 \mathrm{~min}$ in an ice-water bath (J. P. Selecta, Abrera, Spain). Samples were centrifuged at $17,400 \times \mathrm{g}$ for $10 \mathrm{~min}$ at $4{ }^{\circ} \mathrm{C}$ (Beckman Coulter, Brea, CA, USA) and aliquots of $7.0 \mathrm{~g}$ of the methanolic extract were evaporated until dryness under $\mathrm{N}_{2}$ flux. Samples were dissolved in $1 \mathrm{~mL}$ mobile phase A (water-methanol-phosphoric acid 94.6:5.0:0.4 v/v/v, pH 2.5) and filtered through $0.2 \mu \mathrm{m}$ PTFE membrane and injected $(80 \mu \mathrm{L})$ into the chromatographic system. Separation and quantification was performed in a Waters 1525 HPLC-DAD system equipped with $4.6 \mathrm{~mm}$ id $\times 150 \mathrm{~mm} \mathrm{RP}_{18} \mathrm{BEH}$ column (Waters, Milford, MA, USA), using a linear gradient (30\% B to 55\% B in $45 \mathrm{~min}$ at $1.1 \mathrm{~mL} \mathrm{~min}^{-1}$ flow rate) of mobile phase $B$ (methanolphosphoric acid 99.98:0.02 v/v, pH 2.5) and mobile phase A. The DAD acquired in the range of $210-450 \mathrm{~nm}$ and peaks were identified according to retention times and UV spectra of pure commercial standards: 5-caffeoylquinic acid (Sigma-Aldrich, Madrid, Spain), quercetin-3-O-rutinoside (Sigma-Aldrich, Madrid, Spain), kaempferol-3-O-rutinoside (Extrasynthèse, Genay, France), naringenin (Sigma-Aldrich, Madrid, Spain) and naringenin chalcone (Apin, Abingdon, UK).

UHPLC-DAD-MS/MS experiments were also carried out to support the tentative identification of dicaffeoylquinic acids I and II, tricaffeoylquinic acid and quercetin trisaccharide. The system consisted of an Acquity UPLC (Waters, Milford, MA, USA) with DAD set at the $210-150 \mathrm{~nm}$ range and a triple quadrupole mass spectrometer with electrospray ionization (ESI-TQD). The separation was carried out using an Acquity Shield $\mathrm{RP}_{18} \mathrm{BEH}$ column $(1.0 \mathrm{~mm}$ id $\times 150 \mathrm{~mm})$ and a linear gradient elution from $100 \%$ mobile phase A (water-acetonitrile-formic acid 94.9:5.0:0.1 v/v/v) to $28 \%$ mobile phase B (water-acetonitrile-formic acid 39.9:60.0:0.1, v/v/v) in $25 \mathrm{~min}$, at a flow rate of $0.130 \mathrm{ml} \mathrm{min}^{-1}$. The ESI-TQD operated in negative mode and experiments were performed in scan mode (MS) and product ion scan mode (MS/MS), obtaining the $\mathrm{m} / \mathrm{z}^{-}$values of parent ions and their fragmentation Patterns. Levels of carotenoids in tomatoes expressed as $\mathrm{mg} \mathrm{kg}^{-1} \mathrm{fw}$ in relation to agronomic procedures (means of 8 replicates).

\begin{tabular}{|c|c|c|c|c|c|c|c|c|c|}
\hline Variety & Ripeness & Elicitor & $\mathrm{N}$ dose & Lutein & Lycopene & $\beta$-Carotene & Phytoene & Phytofluene & Sum of carotenoids \\
\hline \multirow[t]{8}{*}{ Caramba } & \multirow[t]{4}{*}{5} & \multirow[t]{2}{*}{ Sulfur } & Low & 2.47 & 3.24 & 2.62 & 0.64 & 0.08 & 9.05 \\
\hline & & & Standard & 2.88 & 3.61 & 3.77 & 0.80 & 0.13 & 11.19 \\
\hline & & \multirow[t]{2}{*}{ Milsana } & Low & 2.09 & 2.83 & 3.34 & 0.54 & 0.03 & 8.83 \\
\hline & & & Standard & 1.70 & 4.31 & 3.14 & 0.85 & 0.09 & 10.09 \\
\hline & \multirow[t]{4}{*}{10} & \multirow[t]{2}{*}{ Sulfur } & Low & 1.62 & 48.63 & 7.66 & 6.69 & 1.29 & 65.89 \\
\hline & & & Standard & 1.81 & 34.49 & 6.53 & 7.80 & 1.71 & 52.34 \\
\hline & & \multirow[t]{2}{*}{ Milsana } & Low & 0.98 & 36.64 & 6.13 & 4.83 & 1.24 & 49.82 \\
\hline & & & Standard & 1.23 & 42.26 & 5.83 & 6.41 & 1.61 & 57.34 \\
\hline \multirow[t]{8}{*}{ Montserrat } & \multirow[t]{4}{*}{5} & \multirow[t]{2}{*}{ Sulfur } & Low & 4.51 & 9.99 & 5.79 & 2.37 & 0.31 & 22.97 \\
\hline & & & Standard & 3.57 & 8.35 & 5.38 & 2.10 & 0.27 & 19.67 \\
\hline & & \multirow[t]{2}{*}{ Milsana } & Low & 2.72 & 6.12 & 5.10 & 1.24 & 0.24 & 15.42 \\
\hline & & & Standard & 3.59 & 6.89 & 4.05 & 1.48 & 0.19 & 16.20 \\
\hline & \multirow[t]{4}{*}{10} & \multirow[t]{2}{*}{ Sulfur } & Low & 2.79 & 37.06 & 5.35 & 6.44 & 0.65 & 52.29 \\
\hline & & & Standard & 2.08 & 44.04 & 6.31 & 8.61 & 1.01 & 62.05 \\
\hline & & \multirow[t]{2}{*}{ Milsana } & Low & 2.78 & 25.98 & 6.21 & 5.01 & 0.64 & 40.62 \\
\hline & & & Standard & 2.01 & 43.68 & 7.09 & 8.20 & 1.30 & 62.28 \\
\hline \multirow[t]{8}{*}{ Pera-Girona } & \multirow[t]{4}{*}{5} & \multirow[t]{2}{*}{ Sulfur } & Low & 2.48 & 11.69 & 2.88 & 3.04 & 0.43 & 20.52 \\
\hline & & & Standard & 2.00 & 10.06 & 2.68 & 2.41 & 0.41 & 17.56 \\
\hline & & \multirow[t]{2}{*}{ Milsana } & Low & 2.28 & 10.04 & 3.00 & 2.40 & 0.45 & 18.17 \\
\hline & & & Standard & 2.99 & 9.73 & 3.78 & 1.72 & 0.30 & 18.52 \\
\hline & \multirow[t]{4}{*}{10} & \multirow[t]{2}{*}{ Sulfur } & Low & 1.40 & 59.58 & 4.24 & 12.08 & 2.09 & 79.39 \\
\hline & & & Standard & 1.71 & 65.78 & 5.10 & 12.05 & 1.60 & 86.24 \\
\hline & & \multirow[t]{2}{*}{ Milsana } & Low & 2.44 & 33.95 & 3.54 & 7.21 & 1.25 & 48.39 \\
\hline & & & Standard & 2.09 & 40.26 & 4.31 & 7.94 & 1.14 & 55.74 \\
\hline
\end{tabular}

Quantification was made by external calibration with commercial pure standards when available, or as equivalents of the most similar standard (5-caffeoylquinic acid for dicaffeoylquinic acids I and II and tricaffeoylquinic acid; quercetin-3-O-rutinoside for quercetin trisaccharide). All solvents were of HPLC grade (J.T. Baker, Deventer, The Netherlands). Limits of detection (LOD) and quantitation (LOQ) were calculated on the basis of the calibration curves as the concentration corresponding to signal to noise $(s / n)$ of 3 and 10 , respectively.

The data were subjected to MANOVA using the General Linear Model procedure in SPSS (release 18) to identify significant treatment effects and interactions: the agronomic parameters (variety, ripening stage, elicitor and $\mathrm{N}$ dose) were set as independent variables and contents of nutritional compounds (carotenoids, minerals, vitamin $C$ and phenolic compounds) as dependent variables. If significant effects were found $(p<0.05)$, differences between variables were checked by LSD post hoc test.

\section{Results and discussion}

\subsection{Carotenoid levels}

Several studies have investigated the carotenoid levels in raw tomatoes of different varieties, reporting a high range of contents (Khachik et al., 1992; Hart and Scott, 1995).The concentrations of lutein, $\beta$-carotene, lycopene, phytoene and phytofluene in tomatoes here reported are in line with data of literature, despite comparison is often hard because of the great influence of agronomic factors such as varieties and harvest time (Table 1). As expected, ripening process, linked to a noticeable change in fruit pigmentation, increased carotenoid levels $(p<0.001)$ : on the average, lycopene was 6-times ( $42.69 \mathrm{mg} \mathrm{kg}^{-1} \mathrm{fw}$ vs. $7.23 \mathrm{mg} \mathrm{kg}^{-1} \mathrm{fw}$ ), $\beta$-carotene 1.5-times ( $5.63 \mathrm{mg} \mathrm{kg}^{-1} \mathrm{fw}$ vs. $3.8 \mathrm{mg} \mathrm{kg}^{-1} \mathrm{fw}$ ), phytoene 5-times ( $7.77 \mathrm{mg} \mathrm{kg}^{-1} \mathrm{fw}$ vs. $1.63 \mathrm{mg} \mathrm{kg}^{-1} \mathrm{fw}$ ) and phytofluene 6-times ( $1.29 \mathrm{mg} \mathrm{kg}^{-1} \mathrm{fw}$ vs. $0.2 \mathrm{mg} \mathrm{kg}^{-1} \mathrm{fw}$ ) higher in ripening stage 10 with respect to 5 . Only lutein concentration showed an opposite trend decreasing its concentration in fruit along with ripening

\subsection{Statistical analysis}


Version définitive du manuscrit publiée dans / Final version of the manuscript published in :

Journal of Food Composition and Analysis (2013), Vol. 31, p. 245-251, DQ!: 1.0.1016/j.jfca.2013.05.014

Journal homepage : www.elsevier.com/locateljfca

Table 2

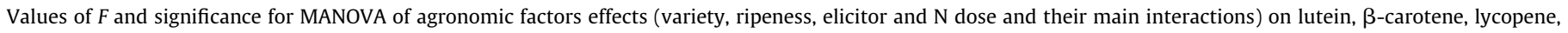
phytoene and phytofluene contents.

\begin{tabular}{|c|c|c|c|c|c|c|c|}
\hline & df & Lutein & $\beta$-Carotene & Lycopene & Phytoene & Phytofluene & Sum of carotenoids \\
\hline Variety V & 2 & $18.988 \mathrm{c}$ & $32.007 \mathrm{c}$ & $5.868 \mathrm{~b}$ & $12.885 \mathrm{c}$ & $7.815 \mathrm{c}$ & $5.023 \mathrm{~b}$ \\
\hline Ripeness R & 1 & $29.552 \mathrm{c}$ & $87.796 \mathrm{c}$ & $275.275 \mathrm{c}$ & $220.088 \mathrm{c}$ & $177.223 \mathrm{c}$ & $279.038 \mathrm{c}$ \\
\hline Elicitor E & 1 & 1.754 & 1.338 & $8.266 \mathrm{~b}$ & $12.018 \mathrm{c}$ & 2.527 & $9.708 \mathrm{~b}$ \\
\hline $\mathrm{N}$-dose $\mathrm{N}$ & 1 & 0.189 & 0.751 & 1.160 & 2.547 & 1.273 & 1.462 \\
\hline $\mathrm{V} \times \mathrm{R}$ & 2 & 1.387 & $12.296 \mathrm{c}$ & 1.857 & 2.498 & $7.440 \mathrm{c}$ & 2.371 \\
\hline $\mathrm{V} \times \mathrm{E}$ & 2 & $5.943 \mathrm{~b}$ & 0.567 & 2.962 & 1.894 & 2.081 & 2.163 \\
\hline $\mathrm{R} \times \mathrm{E}$ & 1 & 2.084 & 0.320 & $5.461 \mathrm{a}$ & $4.822 \mathrm{a}$ & 0.803 & $5.016 \mathrm{a}$ \\
\hline $\mathrm{V} \times \mathrm{N}$ & 2 & 0.925 & 0.957 & 1.058 & 1.106 & $3.140 \mathrm{a}$ & 0.759 \\
\hline $\mathrm{R} \times \mathrm{N}$ & 1 & 0.495 & 0.664 & 1.346 & 3.722 & 2.093 & 1.735 \\
\hline
\end{tabular}

$\mathrm{a}=p \leq 0.05 ; \mathrm{b}=p \leq 0.01 ; \mathrm{c}=p \leq 0.001$.

process. This result, in accordance with the study of Fraser et al. (1994), could be due to inhibition of enzymes catalyzing xanthophylls synthesis in chromoplasts.

In addition to fruit ripeness, tomato variety exerted a significant effects on carotenoid levels as well as the interaction between those two factors (Table 2) that significantly affected $\beta$-carotene and phytofluene $(p<0.001)$. In particular, total carotenoid levels in Pera-Girona variety at the ripening stage 10 resulted significantly higher than the other varieties at the same ripeness $(p<0.05)$ (67.43 $\mathrm{mg} \mathrm{kg}^{-1}$ fw Pera-Girona vs. 54.31 and 56.34 for Montserrat and Caramba, respectively), while a trend toward higher levels of total carotenoids at ripening stage 5 in local varieties than in commercial one was found ( $p=0.06$ ) (Fig. 1) (18.69 and 18.46 vs. 9.78 for Pera-Girona and Montserrat vs. Caramba, respectively). These findings underline the relevance of the agronomic choices to achieve vegetable production with high nutritional value for human nutrition.

The increasing environmentally friendly behavior of consumers leads to the need for testing new approaches against powdery mildew that could be used as alternatives to fungicides and as a valid control measure in low input/organic tomato production system. In the present study, efficacy of Milsana ${ }^{\mathbb{R}}$ was compared to sulfur treatment as plant disease controller, with the expectation to improve or at least to maintain the nutritional value of fruits. The effect of these treatments was significant (Table 2), however Milsana ${ }^{\circledR}$ negatively influenced levels of total carotenoids (33.3 $\mathrm{mg} \mathrm{kg}^{-1}$ Milsana $^{\circledR}$ vs. 41.6 sulfur; $p<0.01$, expressed as mean level) and specifically decreased levels of lycopene (21.7 $\mathrm{mg} \mathrm{kg}^{-1}$ Milsana ${ }^{\circledR}$ vs. 28.0 sulfur, $p<0.01$ ) and phytoene (4.0 $\mathrm{mg} \mathrm{kg}^{-1}$ Milsana $^{\circledR}$ vs. 5.4 sulfur, $p<0.001$ ). Finally, in

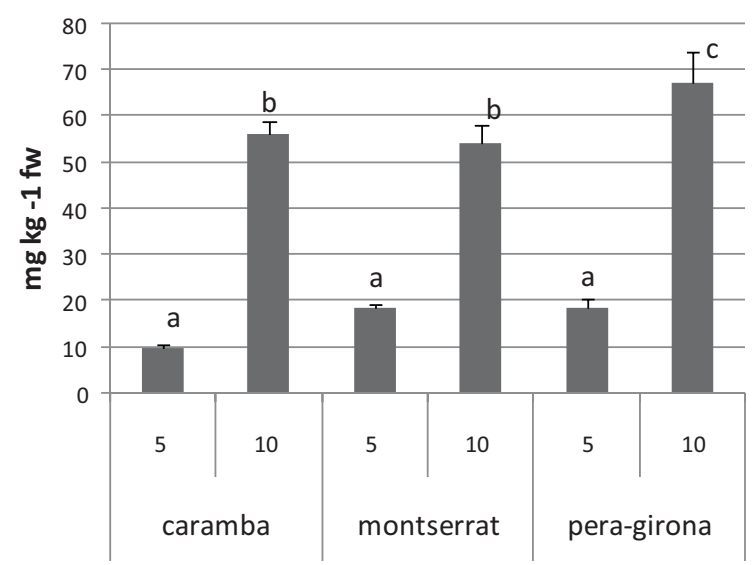

Fig. 1. Levels of total carotenoids ( $\mathrm{mg} \mathrm{kg}^{-1}$ fresh weight) in relation to varieties and ripening stages (mean $\pm \mathrm{SEM}, n=32$ ). Data marked with different letters are significantly different $(p<0.05)$. accordance with Benard et al. (2009), no significant effect was observed in relation to nitrogen level of nutrient solutions.

\subsection{Ascorbic acid and polyphenol levels}

The ingestion of a serving size $(\sim 200 \mathrm{~g})$ of fresh tomatoes provides about $30 \%$ and $36 \%$ of the recommended dietary allowances (RDA) for vitamin $C$ for men and women, respectively. Levels of ascorbic acid found in the present study are consistent with some data reported in literature (Gautier et al., 2008), but higher than others (Anza et al., 2006; Mohammed et al., 2011). This disagreement could be due to different experimental variables such as tomato varieties and/or climatic conditions. Vitamin C content was greatly influenced by varieties (Table 3 ): in ascending order Pera Girona $\left(274.9 \mathrm{mg} \mathrm{kg}^{-1} \mathrm{fw}\right.$, expressed as mean level) < Montserrat $\left(298.4 \mathrm{mg} \mathrm{kg}^{-1} \mathrm{fw}\right)<$ Caramba (341.5 $\mathrm{mg} \mathrm{kg}^{-1} \mathrm{fw}$ ). Significant effect was also exerted by ripeness and level of $\mathrm{N}$ in nutritional solution (Table 4), although they were negatively correlated to vitamin $C$ (ripeness $5: 316.6 \mathrm{mg} \mathrm{kg}^{-1} \mathrm{fw}$ vs. ripeness 10: $293.3 \mathrm{mg} \mathrm{kg}^{-1} \mathrm{fw}$; low N-dose: $309.9 \mathrm{vs.} \mathrm{standard}$ $\mathrm{N}$-dose: $300.1 \mathrm{mg} \mathrm{kg}^{-1} \mathrm{fw}, p<0.05$, as mean of all data). Consistent with our results, other studies also found slight increase in the ascorbate values when $\mathrm{N}$ levels were lowered in the nutrient solution (Dumas et al., 2003; Benard et al., 2009); this is probably attributable to a higher foliage development with high $\mathrm{N}$ supply, which reduced light exposure to fruits and therefore could influence negatively the ascorbate levels. The effect of ripeness needs close examination: it is generally considered that vitamin $\mathrm{C}$ increases with ripening process in tomato fruit (Dumas et al., 2003; Gautier et al., 2008), but different behaviors have been reported regarding maturity stages. The maximum concentration of ascorbic acid was found in fruits that turned yellow-orange, while red-overred fruits show lower levels (Abushita et al., 1997; Ilahy et al., 2011), in accordance with our results. This trend has been related to the antioxidant function of vitamin $C$ when the ripening cells absorb high amount of oxygen as a result of increasing rate of respiration. No effect of treatments for plant diseases was found on vitamin C levels.

The most abundant phenolic compounds in our samples were 5-caffeoylquinic acid (5-CaQA) followed by caffeoylquinic acids derivatives (diCaQA I and II; and triCaQA) (Table 3). 5-Caffeoylquinic acid has been detected as the main phenolic compound in some varieties, e.g. Daniella and cherry (Gautier et al., 2008; Vallverdú-Queralt et al., 2013), but not in others (Slimestad and Verheul, 2009; Barros et al., 2012), underlining the great influence of cultivars on this variable. Variety significantly affected phenolic levels (Table 4) $(p<0.001)$ : Montserrat contained the highest amount of the above cited compounds (82.2, 3.1, 13.2 and $6.92 \mathrm{mg} \mathrm{kg}^{-1} \mathrm{fw}$, respectively, expressed as mean level), and Caramba was particularly rich in quercetin derivatives (Q-Tris: 10.93; Q-Rut: $13.04 \mathrm{mg} \mathrm{kg}^{-1} \mathrm{fw}$ ) and naringenin chalcone 
Version définitive du manuscrit publiée dans / Final version of the manuscript published in :

Journal of Food Composition and Analysis (2013), Vol. 31, p. 245-251., DOI: 10.1016/j.jfca.2013.05.014

Journal homepage : www.elsevier.com/locateljfca

Table 3

Levels of vitamin $\mathrm{C}$ and major phenolics in tomatoes expressed as $\mathrm{mg} \mathrm{kg}^{-1} \mathrm{fw}$ in relation to the agronomic procedures (means of 8 replicates).

\begin{tabular}{|c|c|c|c|c|c|c|c|c|c|c|c|c|c|}
\hline Variety & Ripeness & Elicitor & $\mathrm{N}$ dose & $\begin{array}{l}\text { Vitamin C } \\
\left(\mathrm{mg} \mathrm{kg}^{-1}\right)\end{array}$ & $\begin{array}{l}5-\mathrm{CaQA}^{\mathrm{a}} \\
\left(\mathrm{mg} \mathrm{kg}^{-1}\right)\end{array}$ & $\begin{array}{l}\mathrm{DiCaQA} \mathrm{I} \\
\left(\mathrm{mg} \mathrm{kg}^{-1}\right)\end{array}$ & $\begin{array}{l}\text { DiCaQA II } \\
\left(\mathrm{mg} \mathrm{kg}^{-1}\right)\end{array}$ & $\begin{array}{l}\text { TriCaQA } \\
\left(\mathrm{mg} \mathrm{kg}^{-1}\right)\end{array}$ & $\begin{array}{l}\text { Q-Tris } \\
\left(\mathrm{mg} \mathrm{kg}^{-1}\right)\end{array}$ & $\begin{array}{l}\text { Q-Rut } \\
\left(\mathrm{mg} \mathrm{kg}^{-1}\right)\end{array}$ & $\begin{array}{l}\text { K-Rut } \\
\left(\mathrm{mg} \mathrm{kg}^{-1}\right)\end{array}$ & $\begin{array}{l}\text { Nar } \\
\left(\mathrm{mg} \mathrm{kg}^{-1}\right)\end{array}$ & $\begin{array}{l}\text { Nar chalc } \\
\left(\mathrm{mg} \mathrm{kg}^{-1}\right)\end{array}$ \\
\hline \multirow[t]{8}{*}{ Caramba } & \multirow[t]{4}{*}{5} & \multirow[t]{2}{*}{ Sulfur } & Low & 368.17 & 62.34 & 1.78 & 4.58 & 1.81 & 12.72 & 16.98 & 0.34 & 0.27 & 8.01 \\
\hline & & & Standard & 341.80 & 62.72 & 1.87 & 5.42 & 2.02 & 11.65 & 21.04 & 0.40 & 0.49 & 15.69 \\
\hline & & \multirow[t]{2}{*}{ Milsana } & Low & 371.92 & 62.33 & 1.72 & 4.64 & 1.83 & 10.93 & 16.29 & 0.32 & 0.32 & 10.12 \\
\hline & & & Standard & 316.71 & 62.20 & 1.55 & 4.17 & 1.58 & 9.51 & 11.69 & 0.20 & 0.21 & 6.05 \\
\hline & \multirow[t]{4}{*}{10} & \multirow[t]{2}{*}{ Sulfur } & Low & 362.93 & 27.39 & 2.12 & 4.10 & 2.17 & 11.51 & 10.40 & 0.21 & 0.29 & 6.95 \\
\hline & & & Standard & 332.60 & 28.62 & 2.01 & 4.10 & 2.16 & 10.98 & 10.69 & 0.22 & 0.28 & 6.94 \\
\hline & & \multirow[t]{2}{*}{ Milsana } & Low & 312.28 & 29.97 & 2.29 & 4.40 & 2.58 & 10.30 & 9.20 & 0.19 & 0.21 & 6.98 \\
\hline & & & Standard & 326.00 & 31.03 & 2.15 & 4.37 & 2.15 & 9.89 & 8.04 & 0.16 & 0.39 & 8.50 \\
\hline \multirow[t]{8}{*}{ Montserrat } & \multirow[t]{4}{*}{5} & \multirow[t]{2}{*}{ Sulfur } & Low & 312.62 & 90.58 & 2.31 & 9.53 & 3.75 & 2.29 & 1.70 & $<$ LOQ & $<$ LOQ & $<$ LOQ \\
\hline & & & Standard & 311.85 & 107.16 & 3.57 & 15.19 & 7.02 & 2.44 & 2.32 & $<\mathrm{LOQ}$ & $<$ LOQ & $<\mathrm{LOQ}$ \\
\hline & & \multirow[t]{2}{*}{ Milsana } & Low & 307.67 & 95.67 & 2.68 & 11.78 & 4.77 & 3.45 & 2.22 & $<\mathrm{LOQ}$ & $<\mathrm{LOQ}$ & $<\mathrm{LOQ}$ \\
\hline & & & Standard & 322.45 & 105.65 & 2.71 & 12.93 & 5.40 & 3.41 & 2.22 & $<\mathrm{LOQ}$ & $<\mathrm{LOQ}$ & $<\mathrm{LOQ}$ \\
\hline & \multirow[t]{4}{*}{10} & \multirow[t]{2}{*}{ Sulfur } & Low & 281.68 & 74.98 & 3.82 & 16.28 & 9.85 & 1.13 & 2.04 & $<\mathrm{LOQ}$ & $<\mathrm{LOQ}$ & $<$ LOQ \\
\hline & & & Standard & 271.88 & 46.21 & 2.77 & 8.78 & 5.11 & $<\mathrm{LOQ}^{\mathrm{b}}$ & 0.83 & $<\mathrm{LOQ}$ & $<\mathrm{LOQ}$ & $<\mathrm{LOQ}$ \\
\hline & & \multirow{2}{*}{ Milsana } & Low & 293.87 & 65.26 & 3.44 & 14.57 & 9.18 & 0.79 & 1.34 & $<\mathrm{LOQ}$ & $<\mathrm{LOQ}$ & $<\mathrm{LOQ}$ \\
\hline & & & Standard & 285.08 & 72.37 & 3.77 & 16.82 & 10.26 & 1.42 & 2.23 & $<\mathrm{LOQ}$ & $<\mathrm{LOQ}$ & $<\mathrm{LOQ}$ \\
\hline \multirow[t]{8}{*}{ Pera-Girona } & \multirow[t]{4}{*}{5} & \multirow[t]{2}{*}{ Sulfur } & Low & 282.51 & 69.09 & 1.81 & 7.82 & 3.12 & 3.23 & 3.30 & 0.15 & $<\mathrm{LOQ}$ & $<\mathrm{LOQ}$ \\
\hline & & & Standard & 277.61 & 68.38 & 2.12 & 9.80 & 4.15 & 2.37 & 1.76 & $<$ LOQ & $<\mathrm{LOQ}$ & $<$ LOQ \\
\hline & & \multirow[t]{2}{*}{ Milsana } & Low & 308.34 & 76.36 & 1.54 & 7.21 & 2.40 & 3.17 & 3.88 & 0.16 & $<\mathrm{LOQ}$ & $<\mathrm{LOQ}$ \\
\hline & & & Standard & 277.49 & 55.78 & 1.61 & 5.84 & 2.49 & 1.28 & 1.21 & $<$ LOQ & $<$ LOQ & $<$ LOQ \\
\hline & \multirow[t]{4}{*}{10} & \multirow[t]{2}{*}{ Sulfur } & Low & 267.00 & 45.37 & 2.88 & 10.69 & 7.43 & 2.43 & 4.38 & 0.23 & $<\mathrm{LOQ}$ & $<\mathrm{LOQ}$ \\
\hline & & & Standard & 268.94 & 37.29 & 2.11 & 7.63 & 4.12 & 0.65 & 0.90 & $<$ LOQ & $<\mathrm{LOQ}$ & $<\mathrm{LOQ}$ \\
\hline & & \multirow[t]{2}{*}{ Milsana } & Low & 249.29 & 51.94 & 2.69 & 10.14 & 5.82 & 2.08 & 3.74 & 0.23 & $<\mathrm{LOQ}$ & 0.09 \\
\hline & & & Standard & 268.65 & 39.27 & 2.13 & 7.22 & 3.76 & $<\mathrm{LOQ}$ & 0.86 & $<\mathrm{LOQ}$ & $<\mathrm{LOQ}$ & $<$ LOQ \\
\hline
\end{tabular}

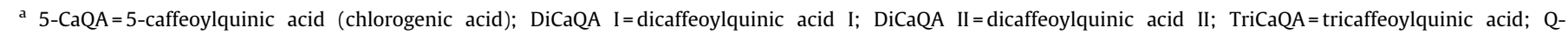
Tris = quercetin trisaccharide; Q-Rut=quercetin-3-O-rutinoside; K-Rut=kaempferol-3-O-rutinoside; Nar=naringenin; Nar Chalc=naringenin chalcone.

b LOQ. Q-Tris $=0.076 \mathrm{mg} \mathrm{kg}^{-1}$; K-Rut $=0.055 \mathrm{mg} \mathrm{kg}^{-1}$; Nar $=0.025 \mathrm{mg} \mathrm{kg}^{-1}$; Nar chalc $=0.090 \mathrm{mg} \mathrm{kg}^{-1}$.

(Nar chalc: $8.66 \mathrm{mg} \mathrm{kg}^{-1} \mathrm{fw}$ ), while containing detectable amounts also of kaempferol-3-O-rutinoside (K-rut: $0.26 \mathrm{mg} \mathrm{kg}^{-1} \mathrm{fw}$ ) and naringenin (Nar: $0.31 \mathrm{mg} \mathrm{kg}^{-1} \mathrm{fw}$ ). The majority of phenols were influenced by ripening stage: green-orange stage had high levels of Q-Rut, Nar chalc and 5-CaQA that decreased with ripeness process (ripeness 5: $76.5 \mathrm{mg} \mathrm{kg}^{-1} \mathrm{fw}$ vs. ripeness $10: 45.8 \mathrm{mg} \mathrm{kg}^{-1} \mathrm{fw}$; $p<0.05)$ in contrast to caffeoylquinic acid derivatives that increased in red fruits, in accordance with data reported in another study (Gautier et al., 2008). In the present study, we observed a trend toward increases of phenolic compounds in tomato treated with low $\mathrm{N}$-dose in nutrient solution, although it resulted significant only for K-Rut and 5-CaQA in Pera-Girona variety (Table 4). A similar slight effect of low nitrogen supply on phenolics was also found in other studies (Stewart et al., 2001; Benard et al., 2009). On the contrary, more important effect of low $\mathrm{N}$ dose was found on phenolic compounds in tomato leaves, in which low $\mathrm{N}$ supply has been reported to induce enzymes of phenolic synthesis pathway (Bongue-Bartlsman and Phillips, 1995). The difference, linked to the plant tissue, is probable due to the highly protected structure of fruit. Negligible effect on Table 4

Values of $F$ and significance for MANOVA of agronomic factors effects (variety, ripeness, elicitor and $\mathrm{N}$ dose and their main interactions) on major phenolic compounds.

\begin{tabular}{|c|c|c|c|c|c|c|c|c|c|c|c|}
\hline & $\mathrm{df}$ & Vitamin C & 5-CaQA ${ }^{\mathrm{a}}$ & DiCaQA I & DiCaQA II & TriCaQA & Q-Tris & Q-Rut & K-Rut & Nar & Nar chalc \\
\hline Variety V & 2 & $100.60 \mathrm{c}$ & $127.11 \mathrm{c}$ & $51.16 \mathrm{c}$ & $151.45 \mathrm{c}$ & $72.21 \mathrm{c}$ & $127.10 \mathrm{c}$ & $156.24 \mathrm{c}$ & $65.18 \mathrm{c}$ & $83.82 \mathrm{c}$ & $278.61 \mathrm{c}$ \\
\hline Ripeness $\mathrm{R}$ & 1 & $36.61 \mathrm{c}$ & $237.44 \mathrm{c}$ & $44.29 \mathrm{c}$ & $4.51 \mathrm{a}$ & $30.84 \mathrm{c}$ & 1.19 & $19.43 \mathrm{c}$ & 1.28 & 1.83 & $6.45 \mathrm{a}$ \\
\hline Elicitor E & 1 & 0.77 & 0.06 & 0.01 & 0.00 & 0.25 & 3.20 & $4.21 \mathrm{a}$ & 2.86 & 0.00 & 1.97 \\
\hline $\mathrm{N}$-dose $\mathrm{N}$ & 1 & $6.43 \mathrm{a}$ & $3.95 \mathrm{a}$ & 1.26 & 0.38 & 0.67 & 0.37 & 3.04 & $13.73 \mathrm{c}$ & 3.24 & 1.59 \\
\hline $\mathrm{V} \times \mathrm{R}$ & 2 & 1.18 & $3.88 \mathrm{a}$ & 0.07 & 2.67 & 2.88 & 2.70 & $15.28 \mathrm{c}$ & $6.44 \mathrm{~b}$ & 0.53 & $6.50 \mathrm{~b}$ \\
\hline $\mathrm{V} \times \mathrm{E}$ & 2 & $4.67 \mathrm{~b}$ & 0.05 & 1.83 & $4.66 \mathrm{a}$ & 1.98 & $4.20 \mathrm{a}$ & $4.49 \mathrm{a}$ & 1.50 & 1.46 & 2.12 \\
\hline $\mathrm{R} \times \mathrm{E}$ & 1 & 1.66 & $5.17 \mathrm{a}$ & $7.54 \mathrm{~b}$ & $5.79 \mathrm{a}$ & $6.21 \mathrm{a}$ & 0.93 & 0.67 & 0.11 & 0.07 & $5.02 \mathrm{a}$ \\
\hline $\mathrm{V} \times \mathrm{N}$ & 2 & $3.71 \mathrm{a}$ & 2.13 & 2.04 & 1.51 & 2.39 & 1.75 & 2.00 & $13.51 \mathrm{c}$ & 0.94 & 1.52 \\
\hline $\mathrm{R} \times \mathrm{N}$ & 1 & $3.73 \mathrm{a}$ & 1.95 & $17.13 \mathrm{c}$ & $15.20 \mathrm{c}$ & $18.62 \mathrm{c}$ & 0.79 & 0.33 & 0.82 & 0.28 & 0.30 \\
\hline $\mathrm{E} \times \mathrm{N}$ & 1 & 0.27 & 0.19 & 0.68 & 0.04 & 0.12 & 0.70 & 1.97 & 0.23 & 0.07 & $6.21 \mathrm{a}$ \\
\hline
\end{tabular}

$\mathrm{a}=p<0.05 ; \mathrm{b}=p<0.01 ; \mathrm{c}=p<0.001$

a 5-CaQA=5-caffeoylquinic acid (chlorogenic acid); DiCaQA I=dicaffeoylquinic acid I; DiCaQA II=dicaffeoylquinic acid II; TriCaQA=tricaffeoylquinic acid; $\mathrm{Q}$-Tris = quercetin trisaccharide; Q-Rut=quercetin-3-O-rutinoside; K-Rut=kaempferol-3-O-rutinoside; Nar=naringenin; Nar chalc=naringenin chalcone. phenolic compounds was also found due to treatments for controlling plant diseases. Published data sustained the efficacy of Milsana ${ }^{\mathbb{R}}$ treatments for inducing phenolic compounds in cucumber (Daayf et al., 2000); however, once again, the cited study evaluated phenolic concentrations only in leaves.

\subsection{Mineral levels}

Although tomato consumption contributes mainly to the intakes of fiber and antioxidant compounds, it plays a role also in covering the adequate intake (AI) for minerals: one serving of tomato ( $200 \mathrm{~g}$ ) represents $10 \%$ of the $\mathrm{AI}$ for $\mathrm{K}$ for all adults, and about 5-7\% of RDA for P and $\mathrm{Mg}$ (Institute of Medicine, 1997, 2005). In the present study, consistently with data of literature (Hernandez Suarez et al., 2007; Guil-Guerrero and RebollosoFuentes, 2009) (Table 5), potassium was the most abundant mineral $\left(2304 \pm 443 \mathrm{mg} \mathrm{kg}^{-1} \mathrm{fw}\right.$, expressed as mean levels of all samples), following by phosphorus $\left(134 \pm 40 \mathrm{mg} \mathrm{kg}^{-1} \mathrm{fw}\right)$ and magnesium $\left(101 \pm 20 \mathrm{mg} \mathrm{kg}^{-1} \mathrm{fw}\right)$; among trace elements the principal element was iron $\left(4.6 \pm 1 \mathrm{mg} \mathrm{kg}^{-1} \mathrm{fw}\right)$. Agronomic 
Version définitive du manuscrit publiée dans / Final version of the manuscript published in :

Journal of Food Composition and Analysis (2013), Vol. 31, p. 245-251, DO!: 1.0.1016/j.jfca.2013.05.014

Journal homepage : www.elsevier.com/locateljfca

Table 5

Levels of minerals in tomatoes expressed as $\mathrm{mg} \mathrm{kg}^{-1} \mathrm{fw}$ in relation to agronomic procedures (means of 8 replicates).

\begin{tabular}{|c|c|c|c|c|c|c|c|c|c|c|c|}
\hline Variety & Ripeness & Elicitor & $\mathrm{N}$ dose & $\mathrm{Fe}$ & $\mathrm{Ca}$ & $\mathrm{Mg}$ & $\mathrm{Cu}$ & $\mathrm{Zn}$ & K & $\mathrm{Na}$ & $\mathrm{P}$ \\
\hline \multirow[t]{8}{*}{ Caramba } & \multirow[t]{4}{*}{5} & \multirow[t]{2}{*}{ Sulfur } & Low & 3.43 & 38.58 & 97.3 & 1.27 & 1.31 & 2370 & 65.9 & 132.9 \\
\hline & & & Standard & 4.51 & 39.81 & 111.0 & 1.41 & 1.73 & 2465 & 85.3 & 175.7 \\
\hline & & \multirow[t]{2}{*}{ Milsana } & Low & 4.70 & 34.23 & 112.6 & 1.28 & 1.80 & 2494 & 53.6 & 156.1 \\
\hline & & & Standard & 4.79 & 38.65 & 95.2 & 1.39 & 1.35 & 2309 & 44.5 & 132.9 \\
\hline & \multirow[t]{4}{*}{10} & \multirow[t]{2}{*}{ Sulfur } & Low & 3.63 & 56.28 & 98.1 & 1.12 & 1.16 & 2284 & 38.8 & 118.6 \\
\hline & & & Standard & 4.38 & 57.09 & 94.9 & 1.03 & 1.14 & 1838 & 50.8 & 117.6 \\
\hline & & \multirow[t]{2}{*}{ Milsana } & Low & 4.13 & 54.43 & 92.9 & 0.84 & 1.13 & 1993 & 27.3 & 101.6 \\
\hline & & & Standard & 4.61 & 58.86 & 100.8 & 1.21 & 1.15 & 2259 & 42.2 & 127.4 \\
\hline \multirow[t]{8}{*}{ Montserrat } & \multirow[t]{4}{*}{5} & \multirow[t]{2}{*}{ Sulfur } & Low & 5.37 & 45.19 & 93.8 & 1.65 & 1.78 & 2400 & 59.7 & 162.8 \\
\hline & & & Standard & 5.42 & 41.23 & 87.8 & 2.26 & 1.72 & 2135 & 61.5 & 133.8 \\
\hline & & \multirow[t]{2}{*}{ Milsana } & Low & 4.55 & 37.74 & 90.2 & 1.66 & 1.76 & 2358 & 74.8 & 151.6 \\
\hline & & & Standard & 4.99 & 43.59 & 90.3 & 1.95 & 1.55 & 2249 & 55.0 & 122.6 \\
\hline & \multirow[t]{4}{*}{10} & \multirow[t]{2}{*}{ Sulfur } & Low & 4.44 & 49.93 & 89.8 & 1.29 & 1.57 & 2029 & 47.6 & 145.8 \\
\hline & & & Standard & 5.94 & 59.04 & 105.6 & 1.49 & 1.47 & 2352 & 47.2 & 150.8 \\
\hline & & \multirow{2}{*}{ Milsana } & Low & 4.90 & 40.25 & 89.5 & 1.30 & 1.74 & 2269 & 71.3 & 155.6 \\
\hline & & & Standard & 5.52 & 52.62 & 101.4 & 1.24 & 1.57 & 2221 & 48.7 & 144.7 \\
\hline \multirow[t]{8}{*}{ Pera-Girona } & \multirow[t]{4}{*}{5} & \multirow[t]{2}{*}{ Sulfur } & Low & 4.69 & 44.93 & 109.7 & 1.55 & 1.55 & 2426 & 40.9 & 131.4 \\
\hline & & & Standard & 4.61 & 51.84 & 107.6 & 1.16 & 1.23 & 2222 & 53.3 & 107.1 \\
\hline & & \multirow[t]{2}{*}{ Milsana } & Low & 4.25 & 43.19 & 96.5 & 1.09 & 1.23 & 2236 & 42.8 & 104.8 \\
\hline & & & Standard & 3.64 & 51.56 & 129.9 & 1.34 & 1.84 & 2968 & 77.0 & 169.0 \\
\hline & \multirow[t]{4}{*}{10} & \multirow[t]{2}{*}{ Sulfur } & Low & 4.01 & 61.93 & 101.1 & 0.99 & 1.06 & 2030 & 24.2 & 117.1 \\
\hline & & & Standard & 5.93 & 65.95 & 120.1 & 1.41 & 1.33 & 2393 & 47.8 & 132.7 \\
\hline & & \multirow[t]{2}{*}{ Milsana } & Low & 4.46 & 43.98 & 111.1 & 0.94 & 1.33 & 2595 & 45.3 & 111.0 \\
\hline & & & Standard & 4.09 & 53.13 & 108.2 & 1.47 & 1.28 & 2423 & 54.4 & 127.0 \\
\hline
\end{tabular}

Table 6

Values of $F$ and significance for MANOVA of agronomic factors effects (variety, ripeness, elicitor and $\mathrm{N}$ dose and their main interactions) on mineral contents.

\begin{tabular}{|c|c|c|c|c|c|c|c|c|c|}
\hline & $\mathrm{df}$ & $\mathrm{Fe}$ & $\mathrm{Ca}$ & $\mathrm{Mg}$ & $\mathrm{Cu}$ & $\mathrm{Zn}$ & K & $\mathrm{Na}$ & $\mathrm{P}$ \\
\hline Variety V & 2 & $13.977 \mathrm{c}$ & 2.668 & $13.516 \mathrm{c}$ & $6.905 c$ & $12.722 \mathrm{c}$ & 2.944 & $4.991 \mathrm{~b}$ & $5.211 \mathrm{~b}$ \\
\hline Ripeness $\mathrm{R}$ & 1 & 0.437 & $29.956 \mathrm{c}$ & 0.092 & $9.711 \mathrm{~b}$ & $19.454 \mathrm{c}$ & $7.417 b$ & $27.863 \mathrm{c}$ & $4.127 \mathrm{a}$ \\
\hline Elicitor E & 1 & 1.130 & $5.146 \mathrm{a}$ & 0.001 & 0.650 & 0.983 & 3.600 & 0.156 & 0.123 \\
\hline $\mathrm{N}$-dose $\mathrm{N}$ & 1 & $12.048 \mathrm{c}$ & $5.643 \mathrm{a}$ & $4.740 \mathrm{a}$ & $4.141 \mathrm{a}$ & 0.013 & 0.196 & $5.399 \mathrm{a}$ & 0.624 \\
\hline $\mathrm{V} \times \mathrm{E}$ & 2 & $6.973 \mathrm{c}$ & 0.852 & 0.096 & 0.109 & 0.395 & 1.839 & $13.396 \mathrm{c}$ & 0.488 \\
\hline $\mathrm{V} \times \mathrm{N}$ & 2 & 1.052 & 0.363 & 1.504 & 0.126 & 1.864 & 1.453 & $10.893 \mathrm{c}$ & $3.611 \mathrm{a}$ \\
\hline $\mathrm{E} \times \mathrm{N}$ & 1 & $7.135 \mathrm{~b}$ & 0.978 & 0.024 & 0.269 & 0.462 & 0.650 & 3.833 & 0.256 \\
\hline $\mathrm{V} \times \mathrm{R}$ & 2 & 1.022 & 2.577 & 2.165 & 1.944 & 2.302 & 1.590 & 2.507 & $4.663 \mathrm{a}$ \\
\hline $\mathrm{R} \times \mathrm{E}$ & 1 & 0.084 & 1.709 & 0.202 & 0.049 & 0.157 & 0.065 & 2.430 & 0.024 \\
\hline $\mathrm{R} \times \mathrm{N}$ & 1 & $5.171 \mathrm{a}$ & 0.401 & 0.691 & 0.101 & 0.008 & 0.084 & 0.007 & 0.550 \\
\hline
\end{tabular}

$\mathrm{a}=p \leq 0.05 ; \mathrm{b}=p \leq 0.01 ; \mathrm{c}=p \leq 0.001$.

conditions largely affect mineral levels: once again, variety and ripening stage appear as the more important factors, although to a minor extent than for carotenoids (Table 6). Average data show that Montserrat cultivar contains higher levels of trace elements and $P$ than the other two cultivars suggesting a direct correlation between these elements, further supported by the analysis of Pearson's coefficient (Table 7). Accordingly, red fruits displayed lower levels of $\mathrm{P}$, but also of $\mathrm{Cu}$ and $\mathrm{Zn}$, with respect to orange fruit $(p<0.05)$. Notwithstanding, the interaction between variety and ripeness exerted a significant effect only on P level (Table 6). Minerals were also influenced by $\mathrm{N}$ dose in nutrient solutions: standard $\mathrm{N}$ dose significantly increased fruit mean contents of Fe with respect to low $\mathrm{N}$

Table 7

Pearson's correlation coefficient and significant levels among levels of analyzed minerals $(n=196)$.

\begin{tabular}{|c|c|c|c|c|c|c|c|}
\hline & $\mathrm{Ca}$ & $\mathrm{Mg}$ & $\mathrm{Cu}$ & $\mathrm{Zn}$ & $\mathrm{K}$ & $\mathrm{Na}$ & $\mathrm{P}$ \\
\hline $\mathrm{Fe}$ & $0.256 \mathrm{c}$ & $0.437 \mathrm{c}$ & $0.456 \mathrm{c}$ & $0.514 \mathrm{c}$ & $0.360 \mathrm{c}$ & $0.192 \mathrm{~b}$ & $0.337 \mathrm{c}$ \\
\hline $\mathrm{Ca}$ & & $0.369 \mathrm{c}$ & 0.105 & 0.018 & $0.171 \mathrm{a}$ & -0.077 & -0.003 \\
\hline $\mathrm{Mg}$ & & & $0.231 \mathrm{c}$ & $0.474 \mathrm{c}$ & $0.814 \mathrm{c}$ & $0.374 \mathrm{c}$ & $0.458 \mathrm{c}$ \\
\hline $\mathrm{Cu}$ & & & & $0.420 \mathrm{c}$ & $0.290 \mathrm{c}$ & $0.280 \mathrm{c}$ & $0.181 \mathrm{a}$ \\
\hline $\mathrm{Zn}$ & & & & & $0.660 \mathrm{c}$ & $0.669 \mathrm{c}$ & $0.662 \mathrm{c}$ \\
\hline $\mathrm{K}$ & & & & & & $0.539 \mathrm{c}$ & $0.578 \mathrm{c}$ \\
\hline $\mathrm{Na}$ & & & & & & & $0.583 \mathrm{c}$ \\
\hline
\end{tabular}

$\mathrm{a}=p \leq 0.05 ; \mathrm{b}=p \leq 0.01 ; \mathrm{c}=p \leq 0.001$. dose ( $4.9 \mathrm{mg} \mathrm{kg}^{-1}$ fw vs. $4.4 \mathrm{mg} \mathrm{kg}^{-1}$ fw, respectively, $p<0.001$ ), Ca (51.2 vs. $45.9, p<0.05)$ and $\mathrm{Mg}(104.4$ vs. $98.4, p<0.05)$. Treatments for controlling plant diseases significantly affected only Ca concentration $(p<0.05)$.

As above mentioned, Pearson's correlation coefficients among analyzed minerals in tomatoes show in particular that $P$ was positively correlated with all the other minerals, with the only exclusion of $\mathrm{Ca}$, and that levels of trace minerals, such as $\mathrm{Fe}, \mathrm{Cu}$ and $\mathrm{Zn}$, were significantly correlated each other (Table 7).

\section{Conclusion}

All crop management factors evaluated in the present study affected levels of nutritional compounds to some degree, sometimes with negative results in relation to specific compounds as in the case of ripeness with respect to phenolics. In addition to the effect of a single agronomic parameter, often their interaction affects the nutrient contents of tomatoes. Varieties and ripening stage were the most important factors affecting carotenoids, minerals, vitamin $\mathrm{C}$ and phenolic compounds. Low $\mathrm{N}$ dose in fertilizer solution seems to exert a positive effect on vitamin $C$ and some phenolics, while the use of elicitor Milsana ${ }^{\mathbb{R}}$ does not appear to be a suitable strategy to positively influence the nutritional quality of tomato. Nevertheless, Milsana ${ }^{\circledR}$ should be considered as a factor for effective control of powdery mildew in greenhouse-grown tomatoes in order to 
improve the sustainability of agricultural practices and limit environmental pollution or farmer risks.

\section{Acknowledgment}

This work was supported by the EU Integrated Project TRUEFOOD (FOOD-CT-2006-016264). The authors thank Elena Viñas, Mariano Bellelli and Jessica Bresciani for their technical assistance.

\section{References}

Abushita, A.A., Hebshi, E.A., Daood, H.G., Biacs, P.A., 1997. Determination of antioxidant vitamins in tomatoes. Food Chemistry 60, 207-212.

Abushita, A.A., Daood, H.G., Biacs, P.A., 2000. Change in carotenoids and antioxidant vitamins in tomato as a function of varietal and technological factors. Journal of Agricultural and Food Chemistry 48, 2075-2081.

Anza, M., Riga, P., Garbisu, C., 2006. Effects of variety and growth season on the organoleptic and nutritional quality of hydroponically grown tomato. Journal of Food Quality 29, 16-37.

Barrett, D.M., Weakley, C., Diaz, J.V., Watnik, M., 2007. Qualitative and nutritional differences in processing tomatoes grown under commercial organic and conventional production system. Journal of Food Science 72, 441-451.

Barros, L., Dueñas, M., Pinela, J., Carvalho, A., Buelga, C., Ferreira, I.F.R., 2012. Characterization and quantification of phenolic compounds in four tomato (Lycopersicon esculentum L.) farmers' varieties in Northeastern Portugal homegardens. Plant Foods for Human Nutrition 67, 229-234.

Benard, C., Gautier, H., Bourgaud, F., Grasselly, D., Navez, B., Caris-Vayrat, C., Weiss, M., Genard, M., 2009. Effect of low nitrogen supply on tomato (Solanum lycopersicum) fruit yield and quality with special emphasis on sugar, acids, ascorbate, carotenoids, and phenolic compounds. Journal of Agricultural and Food Chemistry 57, 4112-4123.

Bongue-Bartlsman, M., Phillips, D.A., 1995. Nitrogen stress regulates gene expression of enzymes on the flavonoid biosynthetic pathway of tomato. Plant Physiology and Biochemistry 33, 539-546.

Bramley, P.M., 2000. Is lycopene beneficial to human health? Phytochemistry 54 233-236.

Daayf, F., Ongena, M., Boulanger, R., El Hadrami, I., Belanger, R.R., 2000. Induction of phenolic compounds in two cultivars of cucumber by treatment of healthy and powdery mildew-infected plants with extract of Reynoutria sachalinensis. Journal of Chemical Ecology 26, 1579-1593.

Dumas, Y., Dadomo, M., Di Lucca, G., Grolier, P., 2003. Effects of environmental factors and agricultural techniques on antioxidant content of tomatoes. Journa of the Science of Food and Agriculture 83, 369-382.

Fiske, C.H., Subbarow, Y., 1925. The colorimetric determination of phosphorus Journal of Biological Chemistry 66, 375

Fofana, B., McNally, D.J., Labbé, C., Boulanger, R., Benhamou, N., Seguin, A., Belanger, R.R., 2002. Milsana-induced resistance in powdery mildew-infected cucumber plants correlates with the induction of chalcone synthase and chalcone isomerase. Physiological and Molecular Plant Pathology 61, 121-132.

Fraser, P.D., Truesdale, M.R., Bird, C.R., Schuch, W., Bramley, P.M., 1994. Carotenoid biosynthesis during tomato fruit development. Plant Physiology 105, 405-413.

Gautier, H., Diakou-Verdin, V., Benard, C., Reich, M., Buret, M., Bourgaud, F., Poessel, J.L., Caris-Veyrat, C., Genard, M., 2008. How does tomato quality (sugar, acid, and nutritional quality) vary with ripening stage, temperature, and irradiance? Journal of Agricultural and Food Chemistry 56, 1241-1250.

Giovannucci, E., Rimm, E.B., Liu, Y., Stampfer, M.J., Willett, W.C., 2002. A prospective study of tomato products, lycopene, and prostate cancer risk. Journal of National Cancer Institute 94, 391-398.

Guil-Guerrero, J.L., Rebolloso-Fuentes, M.M., 2009. Nutrient composition and antioxidant activity of eight tomato (Lycopersicon esculentum) varieties. Journal of Food Composition and Analysis 22, 123-129.

Hart, D.J., Scott, K.J., 1995. Development and evaluation of an HPLC method for the analysis of carotenoids in food, and the measurement of the carotenoids conten of vegetables and fruits commonly consumed in the UK. Food Chemistry 54, $101-111$.

Hernandez Suarez, M., Rodriguez Rodriguez, E.M., Diaz Romero, G., 2007. Mineral and trace element concentrations in cultivars of tomatoes. Food Chemistry 104, 489-499.

Ilahy, R., Hdider, C., Lenucci, M.L., Tlili, I., Dalessandro, G., 2011. Antioxidant activity and bioactive compound changes during fruit ripening of high-lycopene tomato cultivars. Journal of Food Composition and Analysis 24, 588-595.

Institute of Medicine, 1997. Dietary Reference Intakes for Calcium, Phosphorus, Magnesium, Vitamin D and Fluoride. National Academy Press, Washington, DC. Retrieved from: http://www.nap.edu/openbook.php? record_id=5776 (08.09.11).

Institute of Medicine, 2005. Dietary Reference Intakes for Water, Potassium, Sodium, Chloride, and Sulfate. National Academy Press, Washington, DC. Retrieved from: http://www.nap.edu/openbook.php?record_id=10925\&page=186 (08.10.11).

Khachik, F., Goli, M.B., Beecher, G.R., Holden, J., Lusby, W.R., Tenorio, M.D., Barrera, M.R., 1992. Effect of food preparation on qualitative and quantitative distribution of major carotenoids constituents of tomatoes and several green vegetables. Journal of Agricultural and Food Chemistry 40, 390-398.

Klipstein-Grobush, K., Launer, L.J., Geleijnse, J.M., Boeing, H., Hofmann, A., Witteman, J.C., 2000. Serum carotenoids and atherosclerosis: the Rotterdam Study. Atherosclerosis $148,49-56$.

Konstantinidou-Doltsinis, S., Markellou, E., Kasselaki, A.-M., Fanouraki, N., Koumaki, C.M., Schmitt, A., Liopa-Tsakalidis, A., Malathrakis, N.E., 2006. Efficacy of Milasana ${ }^{\mathbb{R}}$, a formulated plant extract from Reynoutria sachalinensis, against powdery mildew of tomato (Leveillula taurica). BioControl 51, 375-392.

Krinsky, N.I., Johnson, E.J., 2005. Carotenoids actions and their relation to health and disease. Molecular Aspects of Medicine 26, 459-516.

Lopez, A., Montano, A., Garcia, P., Garrido, A., 2005. Quantification of ascorbic acid and dehydroascorbic acid in fresh olives and in commercial presentations of table olives. Food Science and Technology International 11, 199-204.

Mohammed, A.E., Smit, I., Pawelzik, E., Keutgen, A.J., Horneburg, B., 2011. Organically grown tomato (Lycopersicon esculentum Mill.): bioactive compounds in the fruit and infection with Phytophthora infestants. Journal of the Science of Food and Agriculture 92, 1424-1431.

Ribas-Agustí, A., Cáceres, R., Gratacós-Cubarsí, M., Sárraga, C., Castellari, M., 2012. A validated HPLC-DAD method for routine determination of ten phenolic compounds in tomato Fruits. Food Analytical Methods 5, 1137-1144.

Ribas-Agustí, A., Bouchagier, P., Skotti, E., Erba, D., Casiraghi, C., Sárraga, C., Castellari, M., 2013. Effects of different organic anti-fungal treatments on tomato plant productivity and selected nutritional components of tomato fruit. Journal of Horticultural Science \& Biotechnology 88, 67-72.

Riso, P., Visioli, F., Erba, D., Testolin, G., Porrini, M., 2004. Lycopene and vitamin C concentrations increase in plasma and lymphocytes after tomato intake. Effects on cellular antioxidant protection. European Journal of Clinical Nutrition 58, 1350-1358.

Simonne, A.H., Fuzeré, J.M., Simonne, E., Hochmuth, R.C., Marshall, M.R., 2007. Effect of nitrogen rates on chemical composition of yellow grape tomato grown in subtropical climate. Journal of Plant Nutrition 30, 927-935.

Slimestad, R., Verheul, M., 2009. Review of flavonoids and other phenolics from fruits of different tomato (Lycopersicon esculentum Mill.) cultivars. Journal of the Science of Food and Agriculture 89, 1255-1270.

Stewart, A.J., Chapman, W., Jenkins, G.I., Graham, I., Martin, T., Crozier, A., 2001. The effect of nitrogen and phosphorus deficiency on flavonol accumulation in plant tissues. Plant Cell and Environment 24, 1189-1197.

Thompson, R.B., Gallardo, M., Rodríguez, J.S., Sánchez, J.A., Magán, J.J., 2013. Effect of $\mathrm{N}$ uptake concentration on nitrate leaching from tomato grown in free-draining soilless culture under Mediterranean conditions. Scientia Horticulturae 150, 387-398.

Vallverdú-Queralt, A., Oms-Oliu, G., Odriozola-Serrano, I., Lamuela-Raventós, R.M., Martín-Belloso, O., Elez-Martínez, P., 2013. Metabolite profiling of phenolic and carotenoid contents in tomatoes after moderate-intensity pulsed electric field treatments. Food Chemistry 136, 199-205.

Willcox, J.K., Catignani, G.L., Lazarus, S., 2003. Tomatoes and cardiovascular heath. Critical Review in Food Science and Nutrition 43, 1-18. 